\title{
NEGOTIATING IDENTITY AND BELONGING IN THE WESTERN INDIAN OCEAN: FLUID ENABLING SPACES IN M.G. VASSANJI'S UHURU STREET
}

\author{
Dolors Ortega \\ Universitat de Barcelona
}

\begin{abstract}
This article analyses the short story cycle Uhuru Street, which describes the life of the members of the minority Ismaili community, whom Vassanji fictionalises as Shamsis, in the context of crucial changes in the history of Tanzania. Diaspora, fragmentation and ethnic multiplicity in a really hierarchical tripartite society will be studied within the framework of cross-cultural networking in the Western Indian Ocean, where complex identity relations are established. Our discussion stems from a brief historical genealogy of the Indian community in Tanzania, it analyses the complex identity relations and affiliations among Tanzanian citizens of Indian descent, and moves on to the analysis of Vassanji's short stories in order to explore those fluid and enabling spaces where identity and belonging are to be negotiated. Keywords: Vassanji, Indian Ocean, Diaspora, Displacement, Fluidity

\section{IDENTIDAD E INTEGRACIÓN EN EL OCÉANO ÍNDICO OCCIDENTAL: ESPACIOS DE NEGOCIACIÓN EN UHURU STREET DE M.G. VASSANJI}

\section{RESUMEN}

El siguiente artículo analiza el ciclo de relatos breves, Uhuru Street, que describe la vida de miembros de la minoría Ismaili, ficcionalizados por Vassanji como los Shamsis, en el contexto de ciertos cambios cruciales para la historia de Tanzania. En este trabajo estudiaremos la diáspora, la fragmentación y la multiplicidad étnica de una sociedad sumamente jerarquizada y tripartita en el marco de las redes interculturales del Océano Índico Occidental, donde se establecen complejas relaciones indentitarias. Nuestra discusión parte de una breve genealogía de la comunidad india en Tanzania, analiza la complejidad de las relaciones identitarias y afiliaciones que existen entre los tanzanos de asendencia india y sigue con el análisis de los relatos cortos de Vassanji para explorar esos espacios fluidos y posibilitadores donde hay una constante negoiación de conecptos como la identidad y el sentido de pertenencia.

Palabras Clave: Vassanji, Océano Índico, Diáspora, desplazamiento, fluidez. 
The Indian Ocean, with its circulation networks, has been characterised as a major interregional crossroads and a fluid space of intense cultural negotiations between various local communities; "[a] great 'highway' for the migrations of peoples, for cultural diffusion, and for economic exchange."(Abu-Lughod 261) Unlike the Pacific and the Atlantic oceans, the Indian Ocean had well established sea routes navigated by Arab, Ethiopian, Persian, Bengali and Chinese trading fleets with tremendously wealthy port cities long before European colonial hegemony. This characteristic provided the Indian Ocean world with an idiosyncratic diversity that has shaped its social, cultural and economic life.

Since antiquity, commercial exchanges brought people of the coast and Arab and Indian ${ }^{1}$ traders in contact with each other. The exchange of goods and ideas went hand in hand with the large-scale traffic in slaves and the connections between Indian Ocean African regions and the Indian Ocean world "ensured important exchanges of capital, people, commodities, technology, and ideas, albeit ones that fluctuated over time, and demonstrate that Indian Ocean Africa played an integral part in the creation and development of 'first global economy" (Campbell 37) before the European arrival.

In fact, Europeans after 1500 did not have a great impact over the Indian Ocean world because the newcomers accommodated themselves to the continuing structures of an Indian Ocean world whose dynamics they hardly understood (Pearson 11). Furthermore, the Indian Ocean was a neuralgic centre of commerce and trade, as well as migration and cultural interaction and it comprised a great transregional exchange network that fostered somehow transnationalism, cosmopolitanism and universalism; identity traits that have permeated Indian Ocean social and cultural transactions over time by questioning solid and stable narratives of nation-states. Individuals and groups in a multiplicity of encounters with others determined their own practices of "cosmopolitan connection," which were diverse in theme, content and duration (Bertz 25). A good example of this is Dar es Salaam, the largest city in East Africa, located in Tanzania, which according to Brennan and Burton has been:

above all a site of juxtaposition between the local, the national, and the cosmopolitan. Local struggles for authority between Shomvi and Zaramo, as well as Shomvi and Zaramo indigenes against upcountry immigrants, stand alongside racialized struggles between Africans and Indians for urban space, global struggles between Germany and Britain for military control, and national struggles between European colonial officials and African nationalists for political control. (13)

${ }^{1}$ As Marie-Aude Fouéré (359) points out, "[b]efore the partition of India in 1947, immigrants from the Indian sub-continent who settled in Tanzania were referred to by the English term "Indians" or its Swahili equivalent Wahindi. Today they are called "Asians" in English and Wahindi in Swahili." I will be using Indian for immigrants and Tanzanian citizens of Indian descent or Indian Tanzanians from the second-third generation onwards. 
After 1800, the Indian Ocean was partially transformed but certain longstanding connections survived colonial rule (especially the British). As Bertz points out, instead of being destroyed by colonialism, "indigenous residents of the Indian Ocean adapted to new political structures and continued to travel, trade and interact across the sea in altered relationships mediated -but not dominated- by Europeans." (28) Both British colonialism and anti-colonial nationalism intensified certain existing transnational linkages across the Indian Ocean world (Bose 2006; Metcalf 2007). The Indian community experience in Tanzania serves as a good example of these linkages across the Indian Ocean.

This article explores Vassanji's work as a meditation on these cultural exchanges regarding Africans of Indian descent in Tanzania. The focus of this study will be on the short story cycle Uhuru Street, which traces the lives of the members of the minority Ismaili community, whom Vassanji fictionalises as the Shamsis, in the context of crucial changes in the history of Tanzania between the 50s and the 80s. Vassanji describes the double migration of the Shamsis to East Africa in the $19^{\text {th }}$ century and from postcolonial Africa towards Europe or North America from the 1960s onwards. Diaspora, fragmentation and multiplicity of ethnic lives in a really hierarchical tripartite society will be studied within the framework of cross-cultural networking in the Western Indian Ocean, where complex identity relations are established. Our discussion stems from a brief historical genealogy of the Indian community in Tanzania, in order to understand the complex identity relations and affiliations among Tanzanian citizens of Indian descent, and moves on to the analysis of Vassanji's short stories in order to explore those fluid and enabling spaces where identity and belonging are to be negotiated.

\section{TANZANIAN CITIZENS OF INDIAN DESCENT: HISTORICAL, SOCIOECONOMIC AND CULTURAL CONFIGURATIONS}

As Brennan asserts, present-day Tanzania cannot be considered a multicultural society in which people of different backgrounds would blend together in harmony; it rather exemplifies a plural society in which people live "side-by-side but separately." (7) Tanzanian society is still divided along racial lines and identity categories, which were built by the state apparatus in colonial times.

The categorisation of a group or person as being Indian, native, or Tanzanian is seen as a performative act connected to political and economic interests of the state, the state's representatives and pressure groups. On the other hand, persons which are subsumed under a category (Indians) as well as those excluded from it (Africans, Arabs, Europeans) are unequivocally affected by these categorisations which in the Tanzanian history of the last one and a half centuries have had substantial repercussions in the legal framework, allotment of political rights and access to economic resources. (Burton 5) 
The first contacts between migrants from the Indian subcontinent and people living along the coast and in the islands of Zanzibar, followed by the impact of colonial rule, contributed to building a sharp socioeconomic and cultural divide between Africans, Arabs and Indians (Fouéré 362). In this section, special attention will be devoted to the ambivalent relations that came up between Africans and Indians as related to the concept of belonging.

While growing numbers of Indian Muslims had first settled in Zanzibar during the Busaidi Sultanate, it was not until the late $19^{\text {th }}$ century that big Indian communities were formed in colonial Tanganyika. Very few Indians had settled on the mainland until the Germans invested in their colony in East Africa, building railways and encouraging commerce in the first decades of the $20^{\text {th }}$ century. These circumstances established the position of Indians as "a middleman minority" (Burton 2), though the community was by no means monolithically well-off, incorporating as it did "humble street traders middling skilled artisans and affluent merchant families such as the Karimjees" (Brennan \& Burton 35). Members of Muslim Shia factions (Ismaili Khojas, Bohoras) were mostly merchants, while Muslim Sunni factions, as well as Hindus, organised in caste groups (jati), were active as shopkeepers and artisans of different professions. As Eric Burton (2013) states, a diaspora is not a uniform or clear-cut group identity. However, despite language, religion, caste, class, and ethnicity differences among Indians, a diasporic pan-communal Indian identity emerged when German colonial policies favoured Indians over other communities. Indians distanced themselves from other communities and strong intracommunity ties were built to reinforce a Pan-Indian Identity.

Furthermore, this diasporic pan-communal identity may be understood as a result of a complex and really hierarchical socioeconomic context which was being forged at the time. German East African society was a highly stratified social apparatus. The white population were missionaries, professional and government servants, and owners and managers of farms, plantations, mines, and other businesses. Many Africans ${ }^{2}$ were government servants, business employees, labourers, and producers of important cash crops, but the great majority, whose living standards were marked by poverty, were self-sufficient, small scale farmers who produced barely enough to survive. Wealthy Africans were excluded from the Indian monopoly on trade as the Indians and Arabs were the middle class and tended to be wholesale and retail traders. The most ambiguous among all these pigeonholed social categories was that of Indians, who, despite being favoured by colonial intervention partly because of their status as British subjects, were perceived as threatening menace by the Germans precisely on the very same grounds. Indians

2 Africans were internally diverse. Swahili merchants, Shirazi or Afro-Shirazi (indigenous people) -divided in three main groups, Wahadimu, Watumbatu and Wapemba- and slaves, who were employed as domestic or farm workers, formed a society that found in Islam their common ground. (Fouéré 361) 
were soon located above the Arabs in the social scale due to the fact that the Arab planter class became heavily indebted because of the suppression of slave-raiding and the commercial slave trade, which was at the basis of their plantation system. As a consequence, Indian creditors could acquire more land and could have the possibility to see their social status promoted. However, the economic situations of Indian immigrants were extremely varied. Well-off merchants were classified along with retailers, small landowners, and impoverished farmers and craftsmen under the single legal category of Indians.

The configuration of these racial categorizations was translated into legal provisions and discriminatory policies, in the social and economic sectors, in urban settings or in ideological apparatuses. The Germans saw the concentration of power by the Indian ascendency as a threatening potential to destabilise the status quo of a colonial world which was based on the assumption that Europeans were superior to all the other racial communities. Therefore, Indians, Arabs and Africans were legally essentialised and categorised as "natives" by the German colonial administration and they did not enjoy the same rights as the white population before the law. In practice, though, Indians enjoyed a preferential treatment in comparison to Arabs and Africans. This left Indians in a very complex social location, since they became the object of resentment or suspicion from every other racial community (Germans, Arabs and Africans).

After the First World War, Tanganyika became a League of Nations mandated territory administered by the British. New economic opportunities opened up in the region and immigration boomed again. Gujarati traders and other Indian migrants moved and settled in East Africa and they were allowed an active role in administration and economy. The British assigned Indians a middle category which gave them more rights than Africans, but still fewer rights than Europeans. Increasing feelings of a common identification among Indians against the British colonial policies in Tanganyika went along with the strengthening of class, religious and political divisions within the community. In Dar es Salaam, the British colonial administrative and commercial capital, the government created three racial zones across the city, splitting the city into racially and/or socially segregated neighbourhoods, which had already been devised by the Germans when they started to build up their new colonial capital (Burton 45-52). The colonial planners segregated the urban spaces on a racial basis following three monolithic categories of race: European, Indian, and African. The first line was drawn between Europeans and non-Europeans, and the second one between natives (including Africans and Arabs) and non-natives (Indians).

European inhabitants were overwhelmingly located in Zone I, which included the old German quarter, northeast of the city centre, and embryonic coastal suburbs to the north. Indians were concentrated in Zone II, the congested bazaar which provided both residential and commercial quarters for what was, between the wars, Dar es Salaam's fastest growing community. The core of the African population was in Kariakoo and, from the late 1920s, in Ilala; though a number of urban 
'villages' were also incorporated within the township boundary, notably Gerezani (demolished in the 1920s/30s) and Keko. (Brennan \& Burton 31)

Such a spatial, economic and ethno-racial segregation between Africans and Indians was especially reinforced by the state through wartime policies of rationing during World War II. Africans and Indians were constructed as opposing communities as James Brennan (2) illustrates:

For most Africans in colonial and early postcolonial Dar es Salaam, that 'Other' was neither the town's tiny European community, which figured so prominently in Africa's settler colonies, nor its similarly small Arab population, which figured so prominently in neighboring Zanzibar. Rather, it was the town's Indian community, who outnumbered Europeans and Arabs combined by nearly four to one, and who constituted roughly one quarter of colonial Dar es Salaam's population.

Indians were socially perceived as powerful property owners whom Africans depended on, even when they were not wealthy business people and their lives as small shopkeepers were closer to Africans' lives in Zone III. Isolated on the outskirts of the city, Africans were excluded from the business world dominated by Europeans and Indians, and they were controlled by new discriminatory laws that were intended to prevent the massive rural exodus of Africans who were seeking new opportunities in the city. Africans were scapegoated by the British administration. There was a constant. precariousness in their lives ${ }^{3}$, and their social status was constantly being denigrated. As was likely to happen, this generated social unrest. The main intercommunity frictions occurred between those who had less social and spatial distance between them, Africans and Indians. Indians occupied that middle position between the British and the Africans. While they were second-class citizens for the British, they were perceived as subjects of privilege by Africans, therefore, becoming the target of their attacks and social unrest.

With Independence, residential segregation and colonial laws that restricted African mobility were officially off the political agenda. Despite being highly racialised, the Tanganyika African National Union (TANU) campaigned its official policy of non-racial nationalism at the Arusha Declaration of 1967, when President Julius Nyerere declared his intention to build a socialist project in Tanzania. However, socioeconomic and racial differentiation remained a marked feature of urban space (Brennan \& Burton 52), and a residual presence of racial thought in the region has intervened in intercommunity relations up to the present. ${ }^{4}$ Once Africans had gained

${ }^{3}$ Fouéré illustrates this by describing the Removal of Undesirable Native Ordinance that forbade "all 'Natives' (Africans) to walk at night without permission and without light, to hold parties or funeral ceremonies without permission, or to stay in Dar es Salaam for more than a week without official written permission." (376)

${ }^{4}$ According to Brennan " $[t]$ he continuation of racial segregation in Dar es Salaam bitterly frustrated African nationalists. For them, urban ujamaa should, above all, result in the eradication of this iniquity. The politics of ujamaa, one observer wrote, was 'to live as a family without regard 
their status as full citizens, Indians were targeted and scapegoated by those who had historically been set to occupy social locations below them. The Africanization of Tanzania had an implicit discriminatory racial effect over Indian people's lives: "Indians were seen as the new representatives of the class of exploiters living upon 'landlordism'. With other privileged groups of Tanzania such as Arabs and the few African capitalists, they were ostracized in a country that aimed to embrace socialism." (Fouéré 382). As a result, a second Indian diaspora to Europe, Canada and North America intensified in the years following Independence. However, with the new president Ali Hassan Mwinyi, those who stayed and had accumulated enough capital (Arab businessmen, African public servants and politicians and Indian merchants) were given the opportunity to participate in a free market economy.

Within such a hierarchical tripartite society it is not difficult to understand that the spirit of conviviality was constantly threatened by frictions, especially between those at the bottom of the social ladder. Economic inequalities between different racial communities in the town brought about a conflicting relationship between these communities. In fact, the general Indian economic advantage created by colonial racial privileges generated a great deal of resentment among the African population, especially in the years preceding and following Independence. As Brennan describes, for Africans "Indians were the shopkeepers on the other side of the counter who bought low and sold high, extracting African wealth between the margins." (8)

\section{BINARY IDENTITY CATEGORIES IN TANZANIA, NATIONAL BELONGING AND VASSANJI'S DIASPORIC CONSCIOUSNESS}

As has been analysed in the previous section, Tanzanian society has historically produced racialised identity categories that problematise the Tanzanian national narrative. What it means to be Tanzanian might vary from group to group at a very specific historical moment, since binary social representations have reproduced identity categories built upon segregating policies and discriminatory conducts. In fact, a deeply rooted circulation of stereotypes has crystallised within the Tanzanian collective consciousness. While Tanzanian Indians have been, and are still, associated with wealth, greed and miserliness, Tanzanian Africans have been, and are still, identified with poverty, laziness and marginality. The stigmatisation of both groups by mutual resentment has constructed the signifiers "African" and "Indian" within an oppositional framework.

to race, wealth, tribe, status, etc.'. He was disheartened, however, to see uzunguni or the European neighbourhood continue to exist, populated by 'Indians, Hindus, Khojas, Europeans', but not one African." (405) 
This proves how identity, a process in itself, is the result of ideological formations. However, though "Ideological State Apparatuses and Repressive State Apparatuses" (Althusser 1971) in Tanzania have interpellated Indian and African communities and have fixed certain identity categories, writers, such as Vassanji, have re-evaluated these categories from other subjective locations. Vassanji writes from an in-between and dislocated space of diaspora, which allows him to move away from systemic cultural impositions towards more fluid identifications. His characters inhabit cross-cultural landscapes. Throughout his work, he observes his syncretic Shamsi community, whose members hold a hybrid identity, Hindu and Muslim, Indian and African:

... I was brought up under a very syncretic tradition... Our names for the imam would be the Hindu names for the Krishna; we would still speak of the Krishna in worshipful terms -a fact which really bothered a lot of mainstream Muslims...

Anything that stinks of purity is just abominable. I personally cannot tolerate these calls to purity. (Rhodes 116)

His fictional Shamsis combine both ethnicity specificities - such as, myths folklore and Cutchi/Gujarati and Swahili terms- and hybridity, approached from a cosmopolitan standpoint. Vassanji understands identity as "a confluence of many streams, a multiplicity of identities; a palimpsest" (Vassanji 17), which is related to the fluid spaces that Indians have inhabited in Africa. As Vassanji suggests "for the Indians in Africa a sense of movement has always been there" (Rhodes 105); an on-going movement that has brought about constant cultural and social negotiations. He writes and recreates the history of those who are dislocated, neither here nor there, diasporic Indians living in East Africa and their further migration to Europe, Canada, or the United States. M.G. Vassanji, a diasporic subject himself ${ }^{5}$, writes "the beyond."

The "beyond" is neither a new horizon, nor a leaving behind of the past... [...] we find ourselves in the moment of transit where space and time cross to produce complex figures of difference and identity, past and present, inside and outside, inclusion and exclusion. For there is a sense of disorientation, a disturbance of direction, in the 'beyond': an exploratory, restless movement caught so well in... here and there... (Bhabha 1-2)

Homi Bhabha's 'beyond' is transitory, liminal, interstitial, hybrid. It is the place where conventional patterns of thought and behaviour can be problematised and revisited by the possibility of crossing. Hybrid identities remain perpetually in motion, open to change and reappropriation. Likewise, Vassanji's characters live

${ }^{5}$ He was born in Nairobi, Kenya, and raised in Dar es Salaam, Tanzania. He moved to the USA to study at MIT, where he received a doctorate in nuclear physics. From the USA he moved to Canada, where he has lived ever since. 
border lives on the border of different nations, in-between different homelands. Migrancy exposes them to displacement, uprooting, fragmentation and discontinuity. They problematise dominant narratives of identity and belonging, which cannot accommodate those who live in-between. His characters mediate cross-cultural exchanges or transculturation and open new transnational spaces for identity and belonging.

Over the years my attachment to the city that shaped me, Dar es Salaam, has remained, despite the changes in cityscape and demography and my belonging more and more elsewhere; when the political climate in Tanzania relaxed, I began to visit it more frequently. In my own way, then, I still belonged to Dar. Belonging is not a privilege given to you, it is not a choice you make; it is a feeling inside you. (Vassanji 32)

Displacement turns the diasporic subject's homeland into an imaginary construct, a series of narratives that he/she keeps with him/her. In Vassanji's foreword to Uhuru Street, he writes: "The Dar es Salaam of these stories is a place in the world of fiction. But it is the real Dar es Salaam, just as it is also the other towns there, on the coast and beyond, through which Uhuru Street runs and seeks access to the world." (xii) Vassanji's story cycle starts by locating "Uhuru Street as both a physical place and a construct with imaginative life in the minds and hearts of those who began life there." (Davis 10). Uhuru Street, an epitome of Dar es Salaam -or Tanzania-, is described as a city without borders; a city that "will follow you."

My first completed work was a collection of stories called Uhuru Street (1991). That street of my childhood runs through most of my fiction -a street beginning in the interior, heading for the ocean and the world, a metaphor for the aspirations of its clamouring children. (Vassanji 32-33)

As Ranjana Tripathi (168) points out, diasporas, as depicted in Vassanji's fictional world in the era of globalisation are better defined in terms of transnationalism networks with a dissolution of cultural and geographic borders among those who leave, those who stay and those who return. Transnational, hybrid and syncretic identities seem to go hand in hand in Vassanji's world. He illustrates this in an interview (Desai 197): "As East Africans, we were Asians and Africans, and my sons feel the same way, besides being Canadian. As Gujarati Khojas we could say Ali and Krishna in the same breath. (I am by no means religious now)." For Vassanji, identity multiplies, it is not to be understood as an "either/or" identification process that excludes, but rather an "and...then...and then..." appropriation of multiple singularities and specificities.

${ }^{6}$ This is a line from C.F. Cavafy's poem "The City," which according to Jacqueline Bardolph (1995) works as an intertext for the title of the short story collection. 
This short story cycle describes an immigrant world populated by members of the minority Ismaili community-Vassanji's community- which is a minority within a minority (Gujarati Khojas). ${ }^{7}$ Double migration and diaspora, the leitmotivs of the cycle, set the scene for the interaction of Indians with the coloniser and the native Africans in a highly stratified tripartite society, and the socio-political frictions that push some Tanzanians of Indian descent to migrate to the Euro-American world from the 60s onwards. As Davis observes:

Europeans, remnants of an imperial age, appear superior; the Africans are beneath the Indians in pre-independence Tanzania, although the roles are reversed after independence. This role-reversal, enacted in several stories, further suggests the inevitability of the departure of the Indians from Tanzania. (16-17)

This collection of short stories is divided by two historical moments, a historical milestone and a turning point that stays at the centre of the cycle. Independence arrives in the ninth story with the renaming of the street that epitomises the world of the Shamsis. Vassanji writes about it in his foreword: "Once Upon a time Uhuru Street was called Kichwele Street. The change marked a great event in the country. Uhuru means 'independence.'” (xi) The street serves as the stage for the changes in status and in the lives of Tanzanians of Indian descent in a socio-historical context marked by Independence. As a result, half of the stories are developed in a colonial context governed by the British, and the other half describes a Post-Independence world for Tanzanian Indians.

The public official narrative of history interacts with the private stories of its anonymous protagonists. Inscribed in the major historical landmark of the cycle (Independence), other different historical events leave their footprint in the lives and world of Vassanji's characters. The First World War, the visit of Queen Margaret to Dar es Salaam, ${ }^{8}$ the campaign for Independence, just to quote a few examples, contribute to understand Vassanji's cycle as a retrospective account of the historical evolution of Tanzanian society.

7 The word Khoja referred to those converted to Nizari Ismaili Islam in the Indian sub-continent from about the thirteenth century onwards. It included certain groups, predominantly from Gujarat and Kutch, who retained strong Indian ethnic roots and caste customs and maintained their Muslim religious identity. While the majority of Khojas remained Ismaili, one group became Ithna' ashari and a smaller group adopted Sunnism. (Asani 2011)

${ }^{8}$ This is a good example of how a historical event contributes to our understanding of the highly racialised context of pre-independent Tanzania. It is interesting to highlight the hyperbolic racialised overtones of this episode. There is a clear foregrounding of the metonymic whiteness of the princess's clothes as contrasted with the black mob "Sitting on Ali's shoulder and looking over the black, fuzzy heads of the mass of people, all straining their eyes and craning their necks, I saw the princess waving a white-gloved hand. Her dress was white and her wide-brimmed hat was also white". (18) 
Emphasis is on the collective experience, a strong sense of community that permeates the cycle. One of the amalgamizing elements among the stories is the fact that, despite being peripheral, some of the characters appear in more than one story, as Davis suggests, to emphasise this idea of collectivity and promote "a collective self, shared by people with a common history and ancestry, providing a consistent frame of reference and meaning" (12) Vassanji's characters are connected by a wide range of circumstances: family relationships, friendship, ethnic group, or gender. They are caught in the labyrinth of identity either by being confronted by colonial divides, or by being subjected to a double displacement that leaves them in a desperate search to find their ambiguous affiliations somewhere in-between two worlds.

The stories in Uhuru Street come together as a story of generations new and old, the former searching for a new identity, the latter, fiercely holding onto the past. (Vahia 9088) They can be grouped following three thematic lines: Intra-community dealings, inter-racial/inter-community relations, and emigration.

\section{INTRACOMMUNITY DEALINGS WITHIN A HIGHLY STRATIFIED INDIAN COMMUNITY}

The Indian narrator of the first story, "In the Quiet of a Sunday Afternoon," lives a life that has been designed for him and woven out of cultural threads articulated by the social pressure and demands of the community. His mother was African, something that will work as a social marker in his life: "we all have a name here. They think I don't know they call me 'Black.' " (2) The narrator is aware of his own genealogy: "I was an orphan half-caste when I married, mother black. I was brought up by an Indian family, half servant and half son, and the night following the arrival of Good Kulsum and German with their proposal, I was told to take it." (9) Although relationships of dependence may be established between the races, boundaries are kept clear, never to be trespassed. Black is going to be signified as Black no matter what life choices he makes. He lives in a colonial world where hierarchies are to be respected.

The identity of Tanzanian Indians was a permanent collective construction, as they placed each other according to class or native village and introduced themselves by tracing their genealogies. German, the narrator's father-in-law, stands as the paragon of an old generation that embraces such values. When German breaks into the neighbour's home to inspect his son-in-law's new acquaintance, he starts the conversation in a rather intimidating way.

'You are the daughter of Jamal Mehiji,' he said at length.

'Yes,' said Zarina.

German loudly cleared his throat as if he were about to spit on the floor, then shuffled off to the door, stuck his head out and spat.

'I knew your father,' he said when he returned. 'What town was he from?'

'Mbinga,' she answered.

'I know that! Where in India?' 
'I don't know. In Cutch or Gujarat somewhere.'

'Mudra,' he said, nodding at me. 'I remember when he came to Africa.'

She said nothing (6)

A generational clash lies behind this conversation. German, who is well aware of the hierarchies that sustain his respectable world of small shopkeepers, pushes Zarina, who does not seem to be so well informed -or even preoccupied-about her own Indian ancestry. For German the Indian pedigree is crucial to understand one's position within the community; for Zarina it does not seem to be an operative signifier any longer. He despises her for coming from a "third class family" (7), as much as, he abominates the children who play in the street: "they are all pigs, all of them." (7) German defines himself in opposition to these members of his own community that do not share his socio-economic status. The narrator, feeling himself an outsider in a world he does not belong to and which is organised around fixed social positions, resolves to leave behind his family to start a new life with Zarina.

Vassanji points at the remarkable social stratification that characterises the Tanzanian Indian community, in which among many other ethnic, religious, and linguistic differences, class or socioeconomic status stand out above all the rest. In "The Relief from Drill," the narrator's brother, who is aware of the importance of social status within his community, tries to improve the lives of the members of his fatherless household by pretending to buy cheap items in an African outdoor market but spending his mother's savings downtown, instead. When the main character persuades the whole family to accept his buying bargains in the African market, the narrator comments: "for a few weeks the quality of life at home improved appreciably. Precisely those things we could not afford to have -whose absence betrayed our modest status, try as hard as we might to hide it- we could now get cheaply. At half the price or less." (45) This family is a good representative of those Tanzanian Indians who, despite not being wealthy business people and although their lives as small shopkeepers were closer to African lives in Zone III, still occupied a very differentiated social position from that of Africans. This is specially clear when the narrator describes the mnada (the open-air market):

The mnada was not a respectable place to shop in because of the type of people believed to hang around there-jobless Africans from the districts, and thieves... And then, popular belief had it, especially in the Indian shops, that the newer and more decent articles there were 'hot' and for that reason dispatched quickly by auction every evening. If an item was stolen from your shop, the chances were that you would find it in the mnada by evening. You could even send your servant to buy it back. (44)

Both the boy narrator and his brother have internalised a segregating discourse under which Africans are denigrated and considered as thieves and criminals. The circulation of such stereotypes has constructed the Mnada street market as a place inhabited by non-respectable peoples in the imagination of these two boys. The narrator's brother wants to enjoy the privileges that the market has allowed him to have, but he does not dare to cross certain boundaries. 
Although Tanzanian Indians defined their identity, generally in opposition to that of the Africans, Vassanji tries to move away from the essentialisation of the Indian community by drawing attention to the differences in perception even within the South Asian community. Every subgroup generally keeps its boundaries closed to the other Indian ethnicities. A good example of this is to be found in "Alzira" when the narrator comments: "the Pereras were Goans and their affairs of little interest to the rest of us." (20) Loyalty to one's ethnic group is evidenced over and over again. This is sharply dramatized in the contrasting reactions of the boy narrator and the Goan Alzira towards Tembombili, "one of Dar's several crazies, a small, thin, Goan man," (27) when he is almost beaten up by a mob and rescued by Alzira's brother, Pius.

\section{INTERCOMMUNITY RELATIONS BETWEEN AFRICANS AND INDIANS}

Although Uhuru Street is a celebration of ethnic diversity, Vassanji denounces the cruelties that have been addressed in both directions, from Indians to Africans and from Africans to Indians. Vassanji's stories embrace multiplicity and diversity in Tanzania, as the narrator in "For a Shilling" describes, Uhuru Street was: "(t)he crazy world of our daily associations-of Arabs, Africans, Asians and assorted halfcastes...” (35).

However, Vassanji's stories focus on the frictions these cultural and ethnic interactions brought about in a society that is clearly divided upon racial lines. Each community has constructed its own identity in opposition to the other racial group, which unavoidably gives way to a constant social unrest that reinforces and distances one group from the other. In "The Sounds of the Night," the young narrator experiences this tension when he bumps into an African man who is heading to the mosque:

'Where are you going to, child?' he said.

'To the mosque.'

'The Indian mosque. What do you do there?'

'We pray.'

'You don't pray, you make fun!' He started mocking. 'Ai-yai-yai-yai,' he sang in a high-pitched voice.'

Partisanship got the better of me and in a rage I cried, 'We don't make fun! We pray! It is you who makes fun!' (67)

The man's ridiculing intention and devaluation of Indians ratifies a divided world that the boy has already internalised when he is about to get to the Indian mosque, which happens to be placed side by side with the African mosque, and specifies which mosque he belongs to: "Not his but ours." (66).

Vassanji illustrates a world governed by racial divides, and even in those stories that are not primarily focused on intercommunity conflicts, we can find evidences of these frictions. This is the case of "The Driver," in which the narrator 
illustrates the many intercommunity tensions in an episode that describes the fights between the Africans and the Arabs in Tanzania:

Early in the morning, every day, a truck came to deliver meat and the event almost always ended at the brink of bloodshed. At an innocuous seeming moment one of the African delivery boys would put a palm to his lips, blow a tremendous fart, and muttering Y'Allah!' like an Arab, pause for a moment. This was the cue. One of the younger butchers would come running out, brandishing a knife, an axe or a steel, swearing in Arabic. 'You son of a dog! Your father's arse!' (53)

Idi the driver, the main character in the story, dismisses violent behaviours and he does not want to be associated with the delivery boys: "In contrast the delivery boys came barefoot and in tatters, hauling large hunks of bloody beef on their backs. No, he thought, as he reached the car, he was definitely not one of them." (53) He wants to move up the social ladder: "He was a driver trained by another driver at the District Commissioner's office in his village and hoping for a government job." (53)

The most devastating story in the cycle is the episode narrated in "What Good Times We Had," which describes the climate of hostility between Tanzanian Indians and Africans in a Post-Independence context that seems to have reversed the social roles" between them: "There was a price for everything here. And after all that, there was no peace to be had even at night, time for fear of robbers. They lived on the edge, not knowing if they would be pushed off the precipice the next." (93) The protagonist, a young woman who feels nostalgia for the past in which Indians were privileged and who is determined to leave the country that is not offering her many more opportunities, sees her dream falling to pieces the moment she is brutally attacked, raped and killed by the man who sells her the flight ticket to move to Canada. When the protagonist realises her inevitable fate, she associates the imminent criminal act she is about to be victim of with an escalating violence that has been historically constructed between African and Indian Tanzanians: "And she thought of all the black men she had presided over almost all her thirtyseven years with scorn...Was this revenge, or plain avarice?" (95) Vassanji inscribes this episode of violence within a systemic violence apparatus that has neatly woven the tension between these two communities.

Apart from the conflicts generated by the difficult coexistence between Africans and Indians in Tanzania, Vassanji tackles the issue of inter-racial relationships, one of the greatest taboos among these communities. This is a fear that is articulated by the resistant mother in "Leaving", who, after giving her blessing to her son Aloo to depart to North America, warns him: "Promise me...promise

9 This change in Tanzanian Indians' social position is especially observed in "Ebrahim and the Business man" which illustrates the effects of the Africanization of Tanzania upon Indian Tanzanian business men: "What Teja was referring to was the recent take-over of properties that were let out for rent in a socialisation move by the government." (98) 
me that if I let you go, you will not marry a white woman." (78) Vassanji describes the clash between old and new values in a Pre and Post-Independence world by contrasting two stories with very different resolutions.

"Ali," the second story in the cycle reveals the implausibility of Inter-racial relationships in colonial times. Ali starts serving at a "modest Indian household" because he is regarded as a suitable village boy: "You could not easily mistake him for one of those shifty characters who made a living by unpegging some item hanging for sale in a crowded store and making a dash for it." (13) The hierarchies within the colonial world and the general insecurity to which Africans are subjected serve as a backd rop for the story: "If he was smart enough, he would pick up the requisite skills and sooner or later move on to employment in a richer home, finally even with a European family -who could tell?" (13) Vassanji describes a stratified society where Indians would occupy a mid-position between the affluent Europeans and the oppressed Africans.

Ali fulfils the social expectations that have been drawn for him till that day he is caught by the narrator: "leaning against the top of the bathroom door and, face pressed against the metal bars, ... looking down through the ventilator window above it at my sister Mehroon taking her afternoon bath. Upon hearing me, he stared, looked at me, and jumped lightly down on the floor. 'I shall marry her.' " (19) Ali's peeping is not what has him dismissed, but his attempt to blur the boundaries that exist between an African servant and the daughter of an Indian household. His worst crime is to attempt to break the taboo of an inter-racial relation and imagine an unknowable and unconceivable future for himself by crossing the line that divides Indians and Africans. Racial stereotypes and vexatious behaviour addressed towards Africans in colonial Tanzania resonate throughout the story; the Mother ridicules him and mocks him on more than one occasion, such as, for example when she intimidates him by asking about his abilities: "Do you clean latrines? Yes Mama, yes Mama, yes Mama, he would answer; and then, only if she liked him, she'd come out with: 'And can you steal?' catching his 'Yes Mama' with a mischievous glint in her eye before he could quite suppress it. (14) Racist stereotypes and cruelties against Africans relate them with marginality and criminality in the Indian collective unconscious.

In Post-Independence Tanzania new opportunities are to be given to those who venture into inter-racial relations. "Breaking Loose" describes the story of Yasmin Rajan, an Indian Tanzanian university student, and Daniel Akoto, "a professor of sociology, on loan from the Government of Ghana" (83). They need to face her family's opposition to their relationship -when her parents meet the professor in their store: "There are no friendships with men -not with men we don't know...' The world is not ready for it-" (87)-, as much as their own contradictions and discussions about ethnic authenticity. The professor's approach to Yasmin underpins a process of identity consciousness in the character: "At first her acknowledgement of her origins seemed to her a reaction against Akoto, the African; yet it seemed to be harking back to the authenticity he had been talking about." (88) It is through her inter-racial relationship with Akoto that she discovers her own identity as a hybrid: 
People, bound by their own histories and traditions, seemed to her like puppets tied to strings: but then a new mutant broke loose, an event occurred, and lives changes, the world changed. She was, she decided, a new mutant. (88)

Vassanjii opens new fluid subject locations, where characters such as Yasmin, affirm their Indian African identity as hyphenated subjects that mutate in multiple ways.

\section{EMIGRATION: CROSSING THE BORDERS OF IMAGINED LANDS}

Some of the stories in the cycle -more specifically "Leaving," "What Good Times We Had," "The London-returned," "Refugee" and "All Worlds are Possible Now"- are haunted by the inevitability of the departure of Indians from PostIndependence Tanzania. A clear example of this is to be found in the main character's thoughts in "Refugee", when he arrives in Germany: "How stupid, he thought, to venture out like this into the unknown. But he had been pushed out, ever so gently. From a sitting-room full of family in Dar into this utter, utter loneliness under an alien sky." (122) Physical, emotional and psychological displacement are experienced by these characters that feel compelled to leave their country. When the narrator in "The London-retuned" gets divorced from Amina, who decides to go back to Dar es Salaam, he re-evaluates his life in Toronto: "I tell myself I walked too far, too north, and left too much behind. We inhabited a thin and marginal world in Toronto, the two of us." (111) Furthermore, the narrator feels doubly displaced. He does not feel rooted anywhere, either in Toronto, or in Tanzania, where, as a London-returned, he was an outsider who went back just for holidays. One of those summers, he met Amina and "these two worlds met." (106) His already problematic sense of belonging is questioned once again when their world together collapses the moment Amina starts building up her community with friends who would gradually settle down with their families in Toronto: "Slowly, Toronto, their Toronto became like Dar, and I [the narrator] was out of it." (112)

As Davis observes: "Life changes for those who leave Dar es Salaam. Geographical distance alters perceptions and modifies attitudes. The stories that tell of immigrant lives emphasize the need to revalidate and accept, or reject, what had been learned at home". (20) Whereas Amina's departure from Tanzania affirms her belonging to her community, the narrator's double displacement -from Dar es Salaam to London and from London to Toronto- leaves him in a limbic space where it is hard to fully belong. The same narrator will be the main character in "All Worlds are Possible Now," which describes his return to Dar in search of home; a home that has become a very problematic concept for him. On his first day back, the narrator identifies a Dar es Salaam that has been constructed and imagined: "It looks the same... Or do I imagine, delude myself it is the same?" (131) Displacement turns the narrator's homeland into an imaginary construct, which is subjected to the fabrications of memory. In fact, Vassanji's story foregrounds the complexity 
that is added to the concept of home in relation to the migrant experience. In a conversation with an old teacher and an old classmate, the difficulties to identify what home is for first generation migrants are reflected.

'Yes. But what is home?' he said.

Fahndo and Almeida, like many of our other Indian teachers, came to East Africa as young men, unlike most of us, their students, who were second and third generation Africans.

'The whole world is our home. It's a global village' grinned Lateef. (135)

These two representatives of the second and third generation of Africans of Indian descent live a second Indian diaspora, which makes it difficult for them to go back to India, as their frame of reference, as their motherland. Likewise, they have a problematic relationship to situate Indianness as a transcendental signifier for their identity and sense of belonging. Instead, Lateef is calling for an open, globalising and transnational understanding of "home", a space with no clear borders, a crossroads of multiple cultural and social negotiations. Both Lateef and the narrator have left Dar and finally returned. They epitomise the ever-existing and on-going transnational linkages across the Indian Ocean world: "The ships that pass here no longer carry portents of faraway impossible worlds." (130) These faraway worlds are no longer impossible or strange. These two characters belong there, here, and somewhere in-between. They are the product of transnationalism, cosmopolitanism and universalism, as they have crossed the threshold of different geographical and cultural contexts. As migrant subjects, they occupy fluid enabling spaces in-between, which allow them to revisit old certainties about identity and belonging.

This story works as a coda for the cycle. It seems a concluding story, in which the narrator realises that there is no "plain longing for a home, a permanence" (139) for him, but a careful understanding of a vibrant city that seems to be constantly changing.

\section{CONCLUDING REMARKS}

Uhuru Street explores the intrinsic diversity that defines Tanzanian society within the framework of the Indian Ocean world. The cycle contains a series of episodic stories that are organised chronologically around Independence and focus on the lives of Africans of Indian descent. Vassanji analyses the complexities of an extremely hierarchical society which has been divided along racial lines since colonial times. His fictional world provides a good vantage point to observe the complex subjective processes of double displacement and the problematic negotiations of intracommunity and transcultural dealings, affecting those who live, those who leave, and those who return to Dar es Salaam, a city which hosts a cosmopolitan population that includes an Indian diaspora and reflects the legacy of long relations with various locations across the Indian Ocean World.

According to Hofmeyr, "[a]t every turn the Indian Ocean complicates binaries, moving us away from the simplicities of the resistant local and the 
dominating global and toward a historically deep archive of competing universalisms." (722) Vassanji's stories conclude with a promising note in this direction. His last narrator's identity seems not to respond to the historically constructed associations with ancestral Indianness, as it is not defined in opposition to Africans, either. This character seems to inhabit a more fluid and enabling space that complicates the binaries of his world. He is an outsider, and as such, he does not fully belong to one single place. He is the sum total of his life experiences in Dar es Salaam, London and Toronto and his identity is an open process that never ceases to become Other.

Reviews sent to author: $11 / 12 / 2020$

Revised paper accepted for publication: 25/01/2021 


\section{WORKS CITED}

Aвu-Lughod, Janet L. Before Hegemony: The World System A.D. 1250-1350. Oxford UP, 1989.

Althusser, Louis. On the Reproduction of Capitalism: Ideology and Ideological State Apparatuses. Verso, [1971] 2014.

Asani, Ali. "From Satpanthi to Ismaili Muslim: The Articulation of Ismaili Khoja Identity in South Asia." A Modern History of the Ismailis: Continuity and Change in a Muslim Community, edited by Farhad Daftary, I.B. Tauris, 2011. 95-128.

Bardolph, Jacqueline. “M.G. Vassanji’s Uhuru Street: A Short Story Sequence by a Canadian African Asian." Journal of the Short Story in English, 24 (1995): 82-93.

Bertz, Ned. "Indian Ocean World Travellers: Moving Models in Multi-sited Research" Journeys and Dwellings: Indian Ocean Themes in South Asia, H. Basu (Ed.). Orient Longman. 2008. 21-60.

Внавна, Homi. The Location of Culture. Routledge, 2004.

Bose, Sugata. A Hundred Horizons: The Indian Ocean in the Age of Global Empire. Harvard University Press, 2006.

Brennan, James R. "Blood Enemies: Exploitation and Urban Citizenship in the Nationalist Political Thought of Tanzania, 1958-1975.” Journal of African History, 47 (2006): 389-413.

Brennan, James R. Taifa: Making Nation and Race in Urban Tanzania. Ohio University Press, 2012.

Brennan, James R. \& Andrew Burton. "The Emerging Metropolis: A history of Dar es Salaam, circa 1862-2000.” Dar es Salaam: Histories from an Emerging African Metropolis, James. R. Brennan, Andrew Burton, \& Yusuf Lawi (Eds.). African Books Collective, 2007. 13-75.

Burton, Andrew. African Underclass: Urbanisation, crime and colonial order in Dar es Salaam. James Currey, 2005.

Burton, Eric. “' ....What Tribe Should We Call Him?’ The Indian Diaspora, the State and the Nation in Tanzania since ca. 1850." Stichproben. Wiener Zeitschrift für kritische Afrikastudien, 13/25 (2013): 1-28.

Campbell, Gwyn. "Africa, the Indian Ocean World, and the 'Early Modern:' Historiographical Conventions and Problems." Journal of Indian Ocean World Studies, 1/1 (2017): 24-37.

Chauduri, K.N. Trade and Civilisation in the Indian Ocean: An Economic History from The Rise of Islam to 1750. Cambridge University Press, 1985.

Clifford, James. “Diasporas.” Cultural Anthropology, 9/3 (1994): 302-338.

Das Gupta, Ashi \& M.N. Pearson (Eds.). India and the Indian Ocean 1500-1800. Oxford University Press, 1987.

Davis, Rocio G. "Negotiating Place: Identity and Community in M.G. Vassanji's Uhuru Street." ARIEL: A Review of International English Literature (ArielE), 30/3 (1999): 7-25.

DesaI, Gaurav. “'Ambiguity is the driving force or the nuclear reaction behind my creativity:' An E-conversation with M.G. Vassanji." Research in African Literatures, 42/3 (2011): 187-197.

FouÉRÉ, Marie-Aude. “'Indians are Exploiters and Africans Idlers!' Identity Formation and SocioEconomic conditions in Tanzania." Indian Africa: Minorities of Indian-Pakistani Origin in Eastern Africa, edited by Michel Adam, Mkuky Nyota Publishers, 2015. 359-396.

Hofmeyr, Isabel “Universalizing the Indian Ocean.” PMLA, 125/3 (2010): 721-729. 
Lohrmann, Ullrich. Voices from Tanganyika: Great Britain, The United Nations and the Decolonization of a Trust Territory, 1946-1961, Lit Verlag, 2007.

Malak, Amin. "Ambivalent Affiliations and the Postcolonial Condition: The Fiction of M.G. Vassanji.” World Literature Today, 67/2 (1993): 277-282.

Mcpherson, Kenneth. The Indian Ocean: A History of People and The Sea. Oxford University Press, 1993.

Metcalf, Thomas. R. Imperial Connections: India in the Indian Ocean Arena, 1860-1920. University of California Press, 2007.

Pearson, Michael N. The Indian Ocean. Routledge, 2003.

Rhodes, Shane. "M.G. Vassanji: An Interview." Studies in Canadian Literature, 22/2 (1997): 105-107.

Tripathi, R. "Transnationalism and the Migrant Minds: The Journey of M.G Vassanji's Diasporic Consciousness." International Journal of Linguistics, Literature and Culture (LLC), 4/2 (2017): 164-179.

Vahia, Aditi. "M.G. Vassanji's Uhuru Street: A Communal Cocoon in a Foreign Land." European Academic Research, 4/10 (2017): 9080-9090.

Vassanji, M.G. Uhuru Street. McClelland \& Stewart Inc, 1992.

Vassanji, M.G. "Creative Conflicts: Multiculturalism in the Mind." Journal of Literature and Aesthetics, Jan-June (1997): 13-18.

Vassanj, M.G. "Looking at Them: The View Across the Street." Transition, 119, "Afro-Asian Worlds" (2016): 22-36. 